Nordisk Tidsskrift for Kriminalvidenskab 2010

\title{
POLITIKERNES INNFLYTELSE PÅ STRAFFUTMÅLINGEN
}

Av høYesteretTSDOMmer, PROFESSOR DR.JUR. MAgnus MatNingSDAL

This article examines the influence of politicians'statements on sentencing outcomes. In this discussion, democracy and the independence of the judiciary must be balanced. The author argues that there is a fundamental difference between statements made in connection with legislation and those made without any such connection - for example in public debates on sentencing. Statements made in connection with legislation should be given considerable weight. The author gives examples of this practise from the supreme courts of Norway and Denmark. The thoroughness of the available legislative history is, however, of considerable importance, especially as regards whether it is possible to see that the legislator knows how the courts sentence the current violation. On the other hand, the author is very sceptical of statements made without connection to legislation. In his opinion, it is wrong to attach significance to such statements. *

\section{Innledning/problemstilling}

"Jeg ønsker ikke å instruere dommere" uttalte justisminister Dørum under åpningen av Det alminnelige norske dommermøtet i 2003. Men om han ikke bare hadde ønsket det, men også hadde forsøkt å gjøre det, hva da? Dette er noe unøyaktig temaet for dette foredraget.

At dømmende virksomhet er og bør være en domstolsoppgave, er selvsagt. Dette kommer for øvrig direkte til uttrykk i den danske grunnlov $\S 3$ som fastsetter at "[d]en lovgivende magt er hos kongen og folketinget i forening. ... Den dømmende magt er hos domstolene". Omvendt er det en lovgiveroppgave å avgjøre hvilke handlinger som skal være straffbare. Konsekvensen av det er at lovgiveren også fastsetter strafferammene.

Disse utgangspunktene er ukontroversielle. Hvor langt våre politikere kan gå, kommer på spissen dersom de går lenger og treffer vedtak eller kommer med utsagn som mer konkret berører straffutmålingen. I praksis kan dette for det første skje ved mer eller mindre detaljerte utsagn i lovmotiver. Men vi har også eksempler på tilsvarende utsagn utenom lovgiverrollen - dels i generell form og dels i tilknytning til saker som ikke er ferdigbehandlet av domstolene. Spørsmålet er hvilken vekt domstolene bør legge på slike utsagn. Demokratihensynet må i begge situasjoner avveies mot hensynet til domstolenes uavhengighet.

Etter min mening går det en grunnleggende sondring mellom utsagn i og utenfor lovgiverrollen. Jeg begynner med utsagn i tilknytning til lovgivning.

* Title in English: The Politician's Influence on Sentencing. Original in Norwegian. 


\section{Utsagn mv. i tilknytning til lovgivning}

I dagens politiske klima er formålet med eventuelle lovendringer normalt å øke straffenivået. Den vanligste metoden er å øke den øvre strafferammen. Et annet alternativ, som også anvendes, er å forhøye minstestraffen. I Norge har vi de senere årene flere eksempler på slik lovgivning - senest ved lov 25. juni $2010 \mathrm{nr}$. 46 som særlig omfatter grove volds- og seksuallovbrudd. En tredje metode er å lovfeste nye momenter som det skal legges vekt på ved straffutmålingen. Et eksempel på det for Norges vedkommende er straffeloven $\S 60$ a, som ble tilføyd i 2003, og som forhøyer den øvre strafferammen dersom handlingen er begått "som ledd i virksomheten til en organisert kriminell gruppe".

I disse tilfellene må det klare utgangspunktet være at domstolene legger vekt på utsagn i forarbeidene om fremtidig straffenivå. Det kunne riktignok tenkes anført at forarbeidene bare har relevans ved lovtolkingen og ikke ved straffutmålingen. Men da lovgiveren er henvist til å gi generelle straffebud med vide strafferammer, er den naturlige konsekvensen at signalene i forarbeidene tillegges betydelig vekt ved straffutmålingen. Jeg tenker da foreløpig på tilfeller hvor utsagnene er av generell karakter, og begrenser seg til å angi den retningen som straffenivået skal bevege seg - med andre ord om det bør skjerpes eller reduseres. Dette er dessuten i realiteten en uttrykkelig konsekvens av selve endringen av strafferammen. I slike tilfeller ville det være illojalt og i dårlig samsvar med demokratihensynet dersom man ikke la vekt på lovgiverens anvisninger. Eller som professor Toftegaard Nielsen uttaler i en artikkel i det danske tidsskriftet Lov \& Ret - 03 Maj 2001: "Jeg synes, det er udtryk for domstolenes respekt for demokratiet, at de, når loven giver et spillerum, skeler til, hvad lovgiver har ønsket med loven”. Motstykket kunne lett bli at nasjonalforsamlingen ble tvunget til å vedta detaljerte straffebud med snevre strafferammer - en utvikling ingen er tjent med. Mitt syn er at vi må unngå å fremprovosere detaljerte straffutmålingstabeller tilsvarende den som for eksempel er utarbeidet for føderale forbrytelser i USA. ${ }^{1}$

Denne holdningen er i samsvar med norsk Høyesteretts praksis. Som eksempel nevner jeg diskusjonen om straffenivået ved voldsforbrytelser hvor det på 1980-tallet oppstod et sterkt politisk ønske om høyere straffenivå. Dette førte til at strl. § 232, som ved nærmere bestemte skjerpende omstendigheter forhøyer den øvre strafferammen for legemskrenkelser, i 1989 fikk et tillegg om at forhøyelse også skulle skje når det forelå "andre særdeles skjerpende omstendigheter". På grunnlag av denne lovendringen, sammenholdt med det som fremgikk av forarbeidene, ble straffenivået ved voldsforbrytelser relativt umiddelbart skjerpet, jf. bl.a. prinsipputtalelsene i Rt. 1990 s. 654,1991 s. 91 og 1991 s. $199 .^{2}$

Det finnes imidlertid også eksempler på at straffenivået har vært angitt mer presist. Slik jeg ser det, er det primært da det prinsipielle spørsmålet kommer på 
spissen. Før jeg går inn på praksis fra vertslandet, Danmark, nevner jeg først et norsk eksempel: Straffenivået for promillekjøring har vært strengt i Norge, og lenge dessuten svært unyansert. Hadde føreren en alkoholkonsentrasjon over 0,5 promille, var straffen fram mot slutten av 1980-tallet som hovedregel 21 dager ubetinget fengsel eller noen få ytterligere dager. Dette ble endret ved lov 8. juli $1988 \mathrm{nr} .70$ hvor promillekjøring ble inndelt i tre kategorier, jf. vegtrafikkloven $\S$ 31. Loven angir nå hva straffen "som regel" skal være innenfor disse kategoriene. For det første utmåles det omtrent alltid en inntektsavhengig bot. I forarbeidene uttales det at den normalt skal tilsvare $1 \frac{1}{2}$ brutto månedslønn. Dette har domstolene med Høyesterett i spissen lojalt fulgt opp. I Rt. 1995 s. 1554 ble det under dissens avgjort at denne retningslinjen fortsatt skulle følges. Videre er det i forarbeidene gitt detaljerte anvisninger om fengselsstraffens lengde ved de ulike påvirkningsnivåene. Også dette synes stort sett å bli etterlevd. ${ }^{3}$

Dansk lovgivning gir også eksempler på forarbeider av denne karakter. Som eksempel nevner jeg at ved endringen av bestemmelsene om legemskrenkelser i straffeloven $\S \S 245$ og 246 ved lov nr. 350 av 23. mai 1997 uttales det:

"[Strafskærpningen] skal ske ved inden for de eksisterende strafferammer at forhøje straffen med gennemgående 1 år i de sager, der falder ind under straffelovens to bestemmelser om den grove vold ( $§ \S 245$ og 246), og hvor der i dag idømmes fængsel i over 1 år."

I høringsuttalelsen uttalte Den danske dommerforening:

"... Imidlertid er en så detaljeret regulering af strafudmålingen i bemærkningerne til et lovforslag ... usædvanlig og rejser principielle problemer om opgavefordelingen mellem domstolene og lovgivningsmagten.

Straffastsættelse, herunder vurdering af, om der foreligger konkret formildende eller skærpende omstændigheder, anses for at være et kerneområde for den "dømmende" myndighed, jf. grundlovens § 3 .

Dommerforeningen finder, at der i bemærkningerne til ... lovforslaget ikke er taget tilstrækkeligt hensyn til domstolenes muligheder og behov for at kunne vurdere den enkelte sag og under hensyn til dens særlige omstændigheder at fastsætte og afbalancere den konkrete straf i forhold til straffastsættelsen på beslægtede områder og til strafniveauet i almindelighed."

Professor Toftegaard Nielsen synes i den nevnte artikkelen fra 2001 å ha liten forståelse for den grunnholdningen som kom til uttrykk i sitatet foran og uttaler: 
"Jo mere detaljeret loven er, jo bedre kan borgeren se sin retsstilling. Det er, hvad der normalt kaldes retssikkerhed, og det er idealet bag grundlovens $\S 3$. Hvordan kan visse dommere så nå til den stik modsatte fortolkning? Det kunne måske være udtryk for, at man læser grundlovens $\S 3$, således at domstolene som den tredje statsmagt skal have en retsskabende eller politisk funktion. Om en "typisk" voldtægt skal medføre en straf på $1 \frac{1}{2}$ års fængsel eller som i Skotland tre års fængsel er dog ikke noget, man bliver kyndigere til at afgøre ved at læse jura."

Betydningen av denne lovendringen for straffenivået ved vold med døden til følge er behandlet i UfR 1999 s. 1599 hvor den domfeltes anke over at straffen var satt til fengsel i seks år ble forkastet. I den sammenheng uttaler Højesteret:

"Ved gennemførelsen af lov nr. 350 af 23. maj 1997 om ændring af straffeloven m.v. tilsigtedes en skærpelse af strafniveauet i de groveste voldstilfælde. Højesteret finder, at straffen i den foreliggende sag må fastsættes under hensyn hertil."

Fra senere praksis nevner jeg forslaget fremsatt 26. februar 2002 til endring i straffeloven vedrørende skjerpelse av straffen for "voldtægt, vold, uagtsomt manddrab, uagtsom betydelig legemsbeskadigelse, forsætlig fareforvoldelse, biltyveri, grov forstyrrelse af ro og orden, menneskesmugling og menneskehandel mv.", og hvor det for hver enkelt overtredelse angis relativt presist hvor omfattende skjerpelse man ønsker. Før proposisjonen ble fremsatt hadde man innhentet en oversikt fra riksadvokaten over straffenivået ved de aktuelle handlingene. Forslaget førte til endring ved lov av 6. juni $2002 \mathrm{nr} .380$.

For voldtekt heter det på s. 7 at "[m]ed den foreslåede forhøjelse af strafferammerne i straffelovens $\S 216$ forudsættes det, at der i retspraksis sker en generel forhøjelse af strafudmålingsniveauet i voldtægtssager i størrelsesorden 1 år i forhold til det strafniveau, der er beskrevet i Rigsadvokatens redegørelse. Det gælder både fuldbyrdede voldtægter og forsøg herpå. Eksempelvis forudsættes det, at straffen for en fuldbyrdet overfaldsvoldtægt i normaltilfældene forhøjes med 1 års fængsel til fængsel i 2 år og 6 måneder."

Videre nevner jeg at da sanksjonene ved promillekjøring ble omlagt med virkning fra 1. juli 2000 slik at det heretter som regel anvendes betinget dom med vilkår om alkoholistbehandling eller samfunnstjeneste i tilfeller hvor det tidligere ble anvendt ubetinget fengsel, ble det i forarbeidene gitt en del direktiver om reaksjonsvalget. Om dette forslaget uttalte Den danske dommerforening: 
"Foreningen er enig i, at det kunne give anledning til principielle betænkeligheder, at lovforslagets bemærkninger indeholder præcise anvisninger, som ikke fremgår af lovteksten, om området for den nye sanktionspraksis og dennes nærmere indhold. Da forslaget imidlertid angår et stort antal sager af ofte ensartet indhold, og da det er af væsentlig betydning, at praksis fra starten ligger nogenlunde fast, har Dommerforeningen ikke bemærkninger til, at man i dette tilfælde har anvendt fremgangsmåden."

I Norge er det nylig vedtatt ny straffelov. Lovens alminnelige del ble vedtatt ved lov 20 . mai $2005 \mathrm{nr} .28$, mens de enkelte straffebudene ble tilføyd ved lov 7. mars 2008 nr. 4 og lov 19. juni 2009 nr. 74. Ved den siste loven ble bl.a. bestemmelsene om volds- og seksuallovbrudd tilføyd. I likhet med hva som ble gjort ved de danske lovvedtakene i 1997 og 2002, inneholder forarbeidene en omfattende gjennomgang av straffutmålingspraksis. Fremgangsmåten er at man i proposisjonen har vist til tidligere høyesterettsdommer og enkelte lagmannsrettsdommer, og deretter antydet fremtidig straffenivå for tilsvarende forhold. På bakgrunn av denne gjennomgangen er det for flere overtredelser angitt et "normalstraffenivå" som for voldtekt til samleie er satt til fengsel i fire år - noe som innebærer en økning på ca. 1 1/4 år i forhold til eksisterende normalstraffenivå. Videre finnes det relativt detaljerte utsagn om avvik - både i skjerpende og formildende retning.

Da det vil ta tid før straffeloven kan tre i kraft, aktualiserte dette spørsmålet om hvilken betydning disse utsagnene skulle tillegges for handlinger begått før lovens ikrafttreden. Spørsmålet ble behandlet av Høyesterett i storkammer med 11 dommere, og dom ble avsagt 13. november 2009, jf. Rt. 2009 s. 1412 og 2009 s. 1423. I Rt. 2009 s. 1412 avsnitt 22 uttaler førstvoterende:

"Det er ingen tvil om at når straffeloven av 2005 trer i kraft, så plikter domstolene å legge til grunn et straffenivå slik det er kommet til uttrykk i lovens forarbeider. Straffutmålingen må skje ut fra dette og under hensyn til de særlige omstendighetene i den enkelte sak."

Om betydningen for handlinger begått for lovens ikrafttreden er dommen avsagt under dissens 10-1. På vegne av flertallet uttaler førstvoterende følgende om forhold begått for lovvedtaket i juni 2009, jf. avsnitt 33:

"For denne gruppen straffbare handlinger er jeg ... kommet til at lovgiverens uttalelser om skjerpet straffenivå i forarbeidene til loven av 2009 ikke kan tillegges noen selvstendig vekt." 
Deretter tilføyes det i avsnitt 34:

"Når det gjelder straffenivået i den foreliggende sak, må det riktige være å ta utgangspunkt i dagens straffenivå, slik det kommer til uttrykk i rettspraksis fra de senere år. Det er tale om et nivå som skrittvis har beveget seg i retning av strengere straff. Slik har det vært både for og etter endringen i bestemmelsene om seksuallovbrudd. Denne utviklingen bør fortsette."

For straffbare handlinger begått i mellomperioden mellom lovvedtaket og lovens ikrafttredelse uttaler førstvoterende i avsnitt 38 at " [h] $\mathrm{h}$ ensynet til forutberegnelighet og til å motvirke at lovgiveren gis mulighet for å påvirke straffutmålingen for straffbare forhold som allerede er begått, er da ivaretatt i en slik grad at forarbeidenes uttalelser om høyere straffenivå skal vektlegges". Deretter fortsetter han slik i avsnitt 39:

"Det er ingen tvil om at forarbeidene på det rettsområdet vi befinner oss på [seksuell omgang med barn], tilsier et vesentlig høyere straffenivå. Spørsmålet er om hele løftet i straffenivå skal tas i ett sprang, eller om det skal skje en mer gradvis skjerpelse av straffen hvor de straffbare handlinger har funnet sted i denne mellomperioden, fra loven ble vedtatt og frem til den trer i kraft. ... Jeg tilføyer at så lenge loven ikke er trådt i kraft, taler hensynet bak tilbakevirkningsforbudet i Grunnloven § 97 og EMK artikkel 7 for at domstolene er varsomme med straffskjerpelser i store sprang, jf. Rt. 1994 side 1552."

Deretter konkluderes det slik i avsnitt 40:

"Ut fra dette mener jeg at utviklingen mot et strengere straffenivå på de aktuelle rettsfeltene bør forsterkes for handlinger som skal avgjøres etter straffeloven 1902, men som er begått etter at 2009-loven ble vedtatt. Perioden mellom vedtakelses- og ikrafttredelsestidspunktet er lang, og prinsippet om at skjerpelsen skal skje gradvis må opprettholdes."

En av dommerne, dommer Skoghøy, hadde derimot et annet grunnsyn, og ville tillegge lovgiversignalene full vekt også for handlinger som er begått før lovens ikrafttreden. I avsnitt 46 uttaler han bl.a.:

"For det tredje vil det som lovgiverne i forbindelse med vedtakelsen av en lov har uttalt om et spørsmål som er undergitt en politisk eller verdimessig vurdering, normalt kunne tas som uttrykk for en allmenn retts- og verdioppfatning 
i samfunnet. Stortinget er demokratisk valgt, og i et parlamentarisk system vil også regjeringen ha en demokratisk forankring. Dersom det ikke finnes holdepunkter for annet, må det verdisyn som er uttalt av Stortinget eller av en parlamentarisk utpekt regjering, kunne tas som et autoritativt uttrykk for den alminnelige rettsfølelse."

I avsnitt 49 uttaler han videre:

"Innenfor de rammer som lovgiverne har fastsatt, er straffutmålingen basert på et sammensatt skjønn, hvor det blant annet må legges vekt på allmenne retts- og verdioppfatninger i samfunnet. Domstolene må ved sin anvendelse av retten være tro mot de demokratiske idealer vårt samfunn er bygd på. I motsetning til dommerne er lovgiverne demokratisk valgt, og ved straffutmålingen må derfor domstolene etter min mening være lydhøre overfor lovgivernes uttalelser. Det syn på straffenivå som kommer til uttrykk i forarbeidene til lovendringen i 2009, har lovgiverne ikke dannet seg 'over natten', men som det fremgår av det jeg har sagt, samsvarer dette med det syn lovgiverne har gitt uttrykk for flere ganger i løpet av de siste ti år. Etter min oppfatning må dette ha som konsekvens at, så lenge det ikke støter an mot tilbakevirkningsforbudene i Grunnloven § 97 og Den europeiske menneskerettskonvensjon (EMK) artikkel 7 , må det syn på straffenivå som kommer til uttrykk i forarbeidene til lovendringen i 2009, også tillegges vekt ved utmåling av straff etter gjeldende straffelov."

Jeg har atskillig sympati for Skoghøys prinsipielle standpunkt.

Norsk Høyesteretts standpunkt er etter dette klart: For handlinger som begås etter et straffebuds ikrafttreden, skal eventuelle signaler i forarbeidene tillegges full vekt. Dette gjelder også når de er såpass presise som ved lovvedtaket i juni 2009. Demokratihensynet er altså gitt fullt gjennomslag. For tidligere handlinger er utgangspunktet det motsatte, men det vil ha stor betydning om handlingen er begått før eller etter lovens vedtakelse.

Den nordiske undersøkelsen av befolkningens holdninger til straff som ble fremlagt i august 2010, indikerer riktignok at befolkningen ønsker et mildere straffenivå enn det som har vært praktisert, mens den norske lovgiveren ved den nye straffeloven derimot tar sikte på en til dels betydelig skjerping av straffenivået for volds- og seksuallovbrudd. Dette er for øvrig allerede gjennomført ved at strafferammene i sentrale bestemmelser i straffeloven 1902 om volds- og seksuallovbrudd ble skjerpet ved lov 25 . juni $2010 \mathrm{nr}$. 46 . Rollefordelingen mellom statsmaktene tilsier imidlertid at domstolene må forholde seg til lovgiveren, og at 
det er lovgiveren som må vurdere om straffenivået eventuelt skal reduseres under henvisning til at befolkningen ønsker et mildere straffenivå.

Før dette punktet avsluttes, må det gjøres to tilføyelser: Dersom departementet i proposisjonen gir uttrykk for et annet standpunkt til fremtidig straffenivå enn flertallet i justiskomiteen, må komiteens standpunkt følges dersom det ikke kommer fram noe under den videre lovbehandlingen som viser at flertallets standpunkt ble fraveket.

For det andre må det kunne legges vekt på kvaliteten av lovarbeidet. Dersom proposisjonen etterlater et inntrykk av at det ikke er foretatt en forsvarlig vurdering av foreslått straffenivå, eksempelvis ved gjennomgang av foreliggende rettspraksis, kan det etter omstendighetene tilsi at forarbeidene tillegges mindre vekt. Dette har man et godt eksempel på i forarbeidene til bestemmelsene om seksuell omgang med barn i den nye norske straffeloven. Der synes man ikke å ha tatt tilstrekkelig inn over seg at ved aldersforskjeller opp til og med ca. tre år og seks måneder til fire år blir gjerningspersonen normalt frifunnet under henvisning til en straffritaksregel om at de involverte er "omtrent jevnbyrdige i alder og utvikling". I lovmotivene synes det ikke å være tatt tilstrekkelig hensyn til at straffen for personer som så vidt har passert denne grensen må være vesensforskjellig i forhold til saker hvor aldersforskjellen er betydelig. Og i motsetning til omtalen av andre volds- og seksuallovbrudd, er det i denne del av motivene ikke vist til konkrete saker. $^{4}$

\section{Utsagn utenom lovgiverrollen}

Etter min mening er det forsøk på å påvirke domstolenes straffutmåling utenom lovgiverrollen det er knyttet flest prinsipielle problemstillinger til. I Norge har vi hatt mange eksempler på det. Det er særlig nivået ved grove volds- og seksuallovbrudd som har vært gjenstand for kritikk, og som har resultert i de endringene som er omtalt foran under punkt 2.

For det første har vi flere eksempler på at det i debatter utenfor Stortinget har kommet klare utsagn fra stortingsrepresentanter om at straffenivået bør skjerpes. Videre har det også kommet til uttrykk kritiske kommentarer til enkeltavgjørelser. Som hovedregel er kritikken fremsatt kort tid etter at dommen er avsagt - altså før den er rettskraftig.

Utsagn av denne karakter kan klart ikke ha selvstendig vekt ved straffutmålingen. Det samme gjelder for spørsmål og svar $i$ Stortingets spørretime. Men her er for øvrig mitt inntrykk at justisministrene gjennomgående er nøye med å understreke maktfordelingsprinsippet.

I Norge har vi videre eksempler på at justiskomiteen i budsjettinnstillinger har kommet med utsagn om at straffenivået på de nevnte områdene bør skjerpes. 
Som eksempel viser jeg til Budsjett-innst. S. nr. 4 (1998-99) hvor en enstemmig justiskomité uttaler (s. 11 første spalte):

"K o m i t e e n vil, som i Budsjett-innst. S. nr. 4 (1997-98), understreke at straffeutmålingen for vold mot barn, sedelighetsforbrytelser og grov voldsbruk bør skjerpes."

Langt på veg tilsvarende enstemmige uttalelser finner man i Budsjett-innst. S. nr. 4 (1999-2000) s. 8 andre spalte og 10 andre spalte. I senere budsjettinnstillinger har jeg ikke sett tilsvarende enstemmige uttalelser, men i Budsjett-innst. S. nr. 4 (2003-2004) finner man i kapitlet om Høyesteretts budsjett en særuttalelse fra Fremskrittspartiet. Etter at en samlet komité har oppfordret påtalemyndigheten til å anke flere straffesaker til Høyesterett, heter det i Fremskrittspartiets særuttalelse:

"Komiteens medlemmer fra Fremskrittspartiet mener det er viktig at landets øverste domstol er seg bevisst de signaler Stortinget har gitt i forhold til å øke straffenivået, og i tilstrekkelig grad tar hensyn til folks rettsoppfatning i forhold til straffeutmåling. Dette er viktig for å opprettholde folks tillit til domstolene."

Slike utsagn er for det første fullstendig malplassert: Stortinget kan ikke på alvor mene at bevilgningene til domstolene skal påvirkes av i hvilken utstrekning de utmåler straffer som Stortinget er tilfreds med. Og skulle utsagnene være slik å forstå, har i tilfelle justiskomiteen passert en totalt uakseptabel grense. Den eneste sammenhengen hvor jeg ville ha forståelse for utsagnet, er i kapitlet om kriminalomsorgen - nærmere bestemt at fordi man arbeider for strengere straffer, må fengselskapasiteten økes med de budsjettmessige konsekvenser det har.

Slike utsagn har undertiden vært påberopt for Høyesterett, men Høyesteretts avgjørelser er kjemisk fri for henvisninger til dem. Dette er etter min mening en riktig holdning.

I to saker om anvendelsesområdet for straffeloven $\S 239$ om uaktsomt drap har Høyesterett uttrykkelig blitt utfordret til å ta standpunkt til betydningen av utsagn av denne karakter. Denne bestemmelsen ble endret i 1988 for å oppnå at flere dødsulykker i trafikken ble bedømt som uaktsomt drap. Men etter kort tid oppdaget man at personer som omgivelsene hadde regnet som "bonus pater familias", ble dømt for uaktsomt drap. Fra enkelte hold ble det derfor hevdet at Høyesterett hadde gått for langt i å anvende bestemmelsen ved trafikkulykker. Og i St.meld. nr. 23 (1991-92) Om bekjempelse av kriminalitet s. 120-121 antydet Justisdepar- 
tementet at det var ønskelig med en viss kursjustering. Dette fikk tilslutning av justiskomiteen. ${ }^{5}$ Under henvisning til dette anførte forsvareren i Rt. 1995 s. 1781 at domfellelse etter straffeloven $\S 239$ krever kvalifisert uaktsomhet. Dette var ikke Høyesterett enig i, og førstvoterende uttalte (s. 1784):

"... Han har vist til Rt 1991 side 216. Henvisningen til lovgiverviljen i nevnte dom gjelder imidlertid uttalelser i forarbeidene ved endring i 1988 av blant annet straffeloven $\S 239$. Slike uttalelser i lovforarbeider står i en annen stilling enn generelle uttalelser i andre stortingsdokumenter om kravet til uaktsomhet i saker om trafikkulykker med dødsfall og spørsmålet om tiltale etter straffeloven $§ 239$ i slike saker."

Standpunktet ble fulgt opp i Rt. 2000 s. 1788: Under en interpellasjonsdebatt i Stortingets spørretime 31. mai 1999 erklærte justisminister Dørum seg enig i at praksis hadde vært for streng. Men da han mente at både Høyesterett og riksadvokaten hadde signalisert en kursjustering, fant han det riktig å avvente utviklingen før det eventuelt ble foreslått en lovendring. ${ }^{6}$ Blant annet under henvisning til dette utsagnet anførte forsvareren at det burde kreves grovere uaktsomhet for domfellelse etter straffeloven $\S 239$ enn etter den alminnelige aktsomhetsbestemmelsen i vegtrafikkloven $\S 3$. Til dette uttalte førstvoterende (s. 1790):

"Jeg kan ikke se at det er grunnlag for Høyesterett til å endre den lovforståelse at aktsomhetsnormen er den samme etter begge bestemmelser. Hvis lovgiver $ø$ øker en annen aktsomhetsnorm ved domfellelse etter $\S 239$, forutsetter det etter min mening at lovens ordlyd endres."

Dermed hadde lovgiveren fătt utfordringen - en utfordring som det omtrent umiddelbart ble tatt fatt i. Ved lov 15. juni 2001 nr. 64 ble $\S 239$ endret på en underlig måte: Det tidligere gjerningsinnholdet var at "[d]en, som ved Uagtsomhed forvolder en andens Død, herunder ved bruk av motorvogn, straffes ...". Gjerningsinnholdet $\mathrm{i}$ den nye bestemmelsen er "[d]en som uaktsomt ved bruk av våpen, ved motorvogn eller på annen måte forvolder en annens død, straffes ...". For å redusere antallet domfellelser for uaktsomt drap i trafikken, tok man altså inn alternativet "bruk av våpen" hvor man ikke tok sikte på å endre rettstilstanden. Lovgivers poeng var at man på en eller annen måte måtte konstruere en lovendring for på denne måten å kunne utforme motiver som Høyesterett må ta hensyn til. Selv om endringen har et underlig preg, ble hensikten oppnådd, jf. Rt. 2002 s. 190 hvor førstvoterende uttaler (s. 193): ${ }^{7}$ 
"Det fremgår av de lovforarbeider som her er gjengitt, at meningen har vært å lempe noe på bindingen mellom aktsomhetsnormen i straffeloven $§ 239 \mathrm{og}$ aktsomhetsnormen i vegtrafikkloven $\S 3$. Denne endring er imidlertid ikke kommet til uttrykk i den nye lovteksten, og lovendringen kan - isolert betraktet - vanskelig oppfattes som en presisering i den retning som forarbeidene gir uttrykk for. Siden det imidlertid her er tale om å foreta en lemping av aktsomhetsnormen i forhold til tidligere praksis og dette også har fått tilslutning fra en enstemmig justiskomite, finner jeg at de forutsetninger som er lagt til grunn i forarbeidene må bli retningsgivende for rettspraksis."

Vi har også hatt et enda mer massivt forsøk på utenom lovgiverrollen å påvirke domstolenes straffutmåling: I Dok. nr. 8: 60 (1997-98) fremmet noen representanter fra Fremskrittspartiet følgende forslag:

"Stortinget vil tilkjennegi at domstolenes straffeutmålingspraksis i saker som gjelder grovere voldskriminalitet som drap, legemsbeskadigelse, voldtekt og sedelighetsforbrytelser mot mindreårige er for lav. Stortinget vil henstille til Høyesterett og landets øvrige domstoler å vurdere om ikke det generelle straffeutmålingsnivå for slike forbrytelser bør skjerpes vesentlig innenfor de någjeldende rammer."

Forslaget ble behandlet i Innst. S. nr. 168 (1997-98). Justiskomiteens flertall var enig $i$ at "straffenivået for grove voldsforbrytelser generelt er for lavt, og at straffenivået bør økes, f.eks. for forsettlig drap og voldtekt. En skjerping av straffenivået vil etter fl e r t a 11 e t s oppfatning være i tråd med den alminnelige rettsfølelse hos folk flest og vil også gi en bedre balanse mellom straffenivået i voldssaker og straffenivået i vinnings- og narkotikasaker". Av prinsipielle grunner kunne flertallet likevel ikke gå inn for forslaget:

"Forslaget i Dokument nr. 8: 60 (1997-98) er utformet på en måte som reiser enkelte spørsmål knyttet til forholdet mellom Stortinget og domstolene. Flertallet mener at slik det foreliggende forslag er utformet er det ikke noe konstitusjonelt til hinder for at det kunne vedtas. ...

Utgangspunktet for domstolenes dømmende virksomhet i straffesaker er Grunnloven $\S 96$ der det heter: 'Ingen kan dømmes uden efter lov, eller straffes uden efter dom.' Etter fl e r t a 11 e t s mening uttrykker loven her sentrale rettssikkerhetsgarantier som er grunnlaget for enhver rettsstat. 
Selv om forslagets form ikke er i strid med konstitusjonen, mener flertallet at det vil være høyst uklart hvilken vekt et vedtak som er foreslått vil kunne bli tillagt.

Videre ser $\mathrm{f} 1 \mathrm{e} \mathrm{r} \mathrm{ta} 11 \mathrm{e} \mathrm{t}$ en fare ved at det vil kunne åpne for en praksis som kan misbrukes til mer direkte politisk styring av domstolenes virksomhet. Det vil etter f 1 e $\mathrm{r}$ t a 11 e t s mening være spesielt uheldig om straffeutmålingspraksis skal kunne gjøres til gjenstand for politisering og vesentlige endringer avhengig av skiftende flertall på Stortinget.

Forslaget åpner for en ny måte å kommunisere på mellom Storting og domstolene, som etter flertallets syn ikke er ønskelig. Flertallet mener at dagens kommunikasjonsform mellom Storting og domstoler bør opprettholdes, og at dagens praksis tilfredsstiller intensjonene i Grunnlovens $\S 96$.

Det er viktig for flertallet å slå fast at domstolene ikke skal kunne bindes opp av ulike former for meningsytringer fra Stortinget, men bygge sine avgjørelser på lovtolking, og at eventuelle bindende endringer derfor må gis lovs form. I straffeutmålingsbestemmelser kan det gjøres på flere måter, f.eks. ved å gi regler om skjerpende momenter i de aktuelle straffebudene, eller ved å justere strafferammen. Domstolene kan i tillegg, som nevnt ovenfor, legge vekt på komitemerknader som framkommer i andre sammenhenger."

Her var det mye forstandig tale. Men jeg reserverer meg mot avslutningen i siste avsnitt.

Som det fremgår av fremstillingen foran, er jeg svært skeptisk til å legge vekt på politikernes utsagn om ønsket straffenivå når slike utsagn fremsettes utenom lovgiverrollen. Det er lovgiveren, domstolene skal forholde seg til. Men dette krever en viktig tilføyelse: Et ønske om høyere straffer kan være begrunnet i økt innsikt om skadevirkningene av de aktuelle forbrytelsene, av endrete forhold mv. Dette er selvsagt relevant ved straffutmålingen. Mitt poeng er at de nevnte uttalelsene ikke har selvstendig vekt. Domstolene lever dessuten ikke i et vakuum. Det er derfor en grense for hvor stort spriket kan være mellom hva folk flest oppfatter som en passende straff og de straffene som utmåles av domstolene. Men i denne sammenheng er det også viktig å være oppmerksom på at folks oppfatning om faktisk straffenivå ofte viser seg ikke å være i samsvar med de reelle forhold - noe den nordiske undersøkelsen om befolkningens holdninger til straffenivå som ble fremlagt $\mathrm{i}$ august 2010 indikerer. $^{8}$

Det må også gjøres en ytterligere reservasjon: Dersom departementet i en Stortingsmelding om kriminalpolitikken, med senere tiltredelse fra Stortinget, på samme måten som i forarbeidene til den nye straffeloven gjennomgår sentral rettspraksis, og deretter uttaler hvor mye straffen bør skjerpes, bør dette tillegges 
en viss vekt ved fremtidig straffutmåling. Men så lenge utsagnene ikke gir seg utslag i lovendringer, kan ikke slike utsagn ha samme vekt som utsagn i forarbeidene til en lovendring. I Prop 97 L (2009-2010) s. 11-12 synes derimot departementet å likestille slike utsagn med lovforarbeider. Det går etter min mening i tilfelle for langt.

Min motvilje mot å bygge på utsagn utenom lovgiverrollen er begrunnet i flere forhold. Jeg nøyer meg med å fremheve de jeg legger størst vekt på:

For det første kunne en motsatt praksis over tid føre til en konjunkturbestemt straffutmåling. Til illustrasjon nevner jeg to motpoler i norsk kriminalpolitikk: Inger Louise Valle som var justisminister på slutten av 1970-tallet og Fremskrittspartiets formann, Carl I. Hagen. Valle stod for et langt mildere straffenivå enn Hagen. Hvordan hadde det gått dersom Høyesterett den gang hadde sagt ja vel, statsråd Valle, og senere ja vel, partiformann Hagen?

Etter min mening utgjør det en viktig rettssikkerhetsgaranti at domstolene, som har ansvaret for de lange linjer i straffutmålingen, utmåler straffen uten å legge vekt på hva som uttales i Stortinget utenom lovgiverrollen. Og etter som straffutmålingen synes å bli mer og mer politisert, blir dette stadig viktigere. I denne sammenheng vil jeg referere et utsagn fra professor Greve i boken Straffene, 2. udgave, 2002 s. 244 hvor han kommer inn på at straffene i større utstrekning har blitt parlamentarisk bestemte:

"Det har i samme periode været et gennomgående træk, at politikerne har styrket deres chancer for (gen)valg, hvis de gik ind for hårdere straffe. Det er en udbredt opfattelse, at vi i disse omstændigheder kan finde en væsentlig del af forklaringen på eksplosionen i det u.s. amerikanske fangetal. Hvor de nye opfattelser, som nævnt nedenfor, skulle føre til større retfærdighed, har de i praksis ført til straffe, som ikke opfylder et mindstemål af rimelighed."

Greve er her inne på et vesentlig moment: Det er nok dessverre en kjensgjerning at politikken har blitt mer og mer kortsiktig. Tanken på neste valg blir fremtredende, og de lange linjene uteblir. Når da fjernsynskanalene i diskusjonsprogram i beste sendetid med utgangspunkt $\mathrm{i}$ konkrete saker fokuserer på kriminalpolitiske spørsmål, og hvor ofte viktige nyanser ikke kommer fram, blir politikerne lett fristet til å opptre som værhaner og å henge seg på ofte lite gjennomtenkte rop om strengere straffer. Dommerne har derimot ikke noe kommende valg å tenke på, og bør ha ryggrad til å motstå denne populismen.

Et annet moment er at enkelte politikere ikke viser tilstrekkelig respekt for domstolenes uavhengighet. Som eksempel viser jeg til at den før omtalte Carl I. Hagen, som senere ble Stortingets visepresident, og nå er medlem av Domstol- 
administrasjonens styre, vinteren 2002 foretok en godt forhåndsannonsert tur til Bergen for å være til stede i Gulating lagmannsrett da en velkjent norsk rederdatter begjærte en sak som stod til behandling der, utsatt. Den erklærte hensikten med turen var å påvirke lagmannsretten til å ta begjæringen til følge.

Høsten 2003 fikk vi et nytt eksempel fra samme parti: Da den tiltalte i en sterkt medieomtalt drapssak fra Skien hadde blitt dømt i Agder lagmannsrett for å ha drept sin kone, men på stedet anket dommen til Høyesterett, tok lagmannsretten til følge hans begjæring om løslatelse. Løslatelsen ble kritisert fra forskjellig hold, men lengst gikk nok Jan Arild Ellingsen som på det tidspunktet ofte uttalte seg på partiets vegne om justispolitiske spørsmål. Ifølge Aftenposten lørdag 1. november 2003 skal han ha skrevet på Fremskrittspartiets internettside "at partiet har samarbeidet med Regjeringen for siste gang, dersom ikke justisminister Dørum griper inn i avgjørelsen om å løslate A". Og overfor avisen skal han ha uttalt at "[d]ersom Odd Einar Dørum velger å se en annen vei, er det samtidig et signal om at han ønsker å samarbeide med andre enn oss". Det er skremmende at en person som ofte uttalte seg om justispolitiske spørsmål på vegne av et av landets største partier for det første synes ukjent med at påtalemyndigheten i Norge er underordnet Kongen i statsråd og ikke justisministeren. Videre røper utsagnet at Ellingsen hadde liten forståelse for maktfordelingsprinsippet.

Jeg nevner også et eksempel fra august 1996. Borgarting lagmannsrett løslot en fredag en mann fra varetekt etter at vedkommende i lengre tid hadde vært varetektsfengslet i en sak om seksuelle overgrep mot barn. Løslatelsen var begrunnet $i$ at hans helsetilstand medførte at videre fengsling ville være et uforholdsmessig inngrep. Dette vakte storm i media, og justisminister Faremo, nå norsk forsvarsminister, ble intervjuet på fjernsyn søndag kveld. I intervjuet uttalte hun at hun neste dag skulle sette sine folk i departementet til å gjennomgå saken "fra a til å". Det er selvsagt en oppgave for departementet å følge med i rettspraksis med sikte på å foreslå eventuelle lovendringer. Men det er påtalemyndighetens oppgave å vurdere om en avgjørelse skal ankes.

Når lederen for et så stort parti har vist så liten respekt for domstolenes uavhengighet, og en justisminister kommer med utsagn som det siterte, blir det ekstra viktig at domstolene hegner om sin uavhengighet. Setter vi døren på gløtt for å legge vekt på utsagn utenom lovgiverrollen, kan dette skape mistanke om at dommerne lar seg styre av politikerne i enkeltsaker. Og oppstår det slik mistanke i straffesakene, kan det lett oppstå tilsvarende mistanke i andre saker. En slik utvikling har vi et felles ansvar for å motvirke. Og gis mistanken vekstvilkår, kan tilliten til domstolene bli forspilt.

Betydningen av at domstolene, med Høyesterett i spissen, holder hodet kaldt må derfor ikke undervurderes. Det kan være grunn til å minnes professor An- 
denæs' omtale i Det vanskelige oppgjøret, Oslo 1998 s. 284-285 av at domstolene maktet dette under rettsoppgjøret etter den annen verdenskrig:

"Og hva så med domstolene? Borgernes vern mot overgrep og vilkårlighet i en demokratisk stat. Bestod de prøven? Ja og nei, men jeg synes mest ja. Noen av deres avgjørelser kan diskuteres, noen kritiseres, slik som jeg har gjort i den foregående fremstilling. Kanskje lot de seg, iallfall noen av dem, i de første måneder i for høy grad rive med av den alminnelige stemning. Den nedadgående kurve for straffutmålingen kan tyde på det. Kanskje var det i den forste tid heller ikke alle dommere som i sin ledelse av rettsforhandlingene helt greide å leve opp til de ideelle krav om en nøytral og ikke forutinntatt holdning overfor de tiltalte. Det er iallfall blitt hevdet, og ikke bare av de tiltalte selv. Men studiet av dokumenter og domsgrunner - jeg har selv gått igjennom et par tusen saker - gir et totalinntrykk av grundig og samvittighetsfull prøvelse av den enkelte sak. Domstolene, med Høyesterett i spissen, hevdet sin selvstendighet både overfor de politiske myndigheter og overfor folkestemningen. Det viste seg bl.a. i avgjørelsen av grunnlovsspørsmål, og også på mange andre punkter, f.eks. om bruken av rettighetstap som straff. Dissensene i flere sentrale spørsmål viser problemenes vanskelighetsgrad, men også den enkelte dommers selvstendighet."

Et tredje moment er at utsagn i Stortinget om straffutmåling utenom lovgiverrollen ikke har samme solide og demokratiske grunnlag som forarbeidene til en lov. Folks rettsoppfatninger preges nok $\mathrm{i}$ atskillig utstrekning av pressens ofte unyanserte, ufullstendige og til dels direkte uriktige omtale av verserende saker. Det ville være underlig om ikke stortingsrepresentanters oppfatninger til en viss grad preges av det samme. Til illustrasjon nevner jeg at Asker og Bærum herredsrett rundt tusenårsskiftet avsa en dom som vakte storm i pressen og blant en del stortingsrepresentanter. Men ingen syntes å ha tatt seg bryet med å studere dommen. Da domstolen til slutt følte seg tvunget til å gå ut med en pressemelding om hva domskonklusjonen faktisk gikk ut på, ble det helt taust. Det har forundret meg at våre folkevalgte, som gjentatte ganger må ha opplevd at deres utsagn blir forvrengt av pressen, ikke synes å ha fått med seg at tilsvarende gjelder for pressens omtale av dommer.

Det er også et problem at pressens kritikk av enkeltsaker ofte gjelder atypiske saker, og hvor pressen ikke har fått fram de viktige nyansene i forhold til mer ordinære saker. Sakene gir dermed et skjevt helhetsinntrykk av rettstilstanden.

Dette bringer meg over til mitt siste poeng: Domstolene er sannsynligvis i bedre pakt med folkemeningen enn mange av de folkevalgte. Jeg sikter da til at det 
synes å være en grunnleggende forskjell mellom folks oppfatning om riktig straffenivå når de ser saker omtalt $\mathrm{i}$ avisene, $\mathrm{og}$ når de som meddommere konfronteres med den enkelte sak og den enkelte tiltalte. Jeg mener å ha et godt grunnlag for å uttale meg om dette, idet jeg har totalt $8 \frac{1}{2}$ års dommererfaring fra en domstol i første instans. I denne perioden opplevde jeg ikke en eneste sak hvor en meddommer voterte for strengere straff enn meg. Derimot husker jeg mange saker hvor de ønsket mildere straff, men etter å ha blitt foreholdt Høyesteretts praksis, bøyde de normalt av.

Professor Toftegaard Nielsen uttaler i den nevnte artikkelen at "[d]et kan undertiden virke hult, når lovgiver hævder, at domstolenes strafudmåling ikke er i overensstemmelse med befolkningens retsfølelse. Undertiden tænker man på, om lovgiver kender retsplejelovens regler om lægdommere."

I tillegg til min egen erfaring har jeg foretatt en liten stikkprøve ved å gjennomgå samtlige saker om straffutmålingen ved legemsbeskadigelse, strl. § 229, som Høyesterett avgjorde i 1995 - siste året før to-instansreformen ${ }^{9}$ reduserte antall straffesaker i Høyesterett. Av i alt 22 domfelte skjerpet Høyesterett straffen overfor 15 av dem. Avgjørelsen i herreds- eller byretten var enstemmig i syv av disse sakene, ${ }^{10}$ mens de to meddommerne hadde utgjort flertallet i seks av dem. ${ }^{11}$ I én sak voterte den ene meddommeren for den strengere straffen som Høyesterett utmålte, ${ }^{12}$ mens rettsformannen og den ene meddommeren i en sak voterte for noe strengere straff enn den andre meddommeren. ${ }^{13}$

Om dette momentet minner jeg også om den ferske nordiske undersøkelsen om befolkningens holdninger til straff som trekker i samme retning.

\section{Noter:}

Se Christie: Kriminalitetskontroll som industri, tredje utgave, 2000 s. 140-142.

2 I Rettsteori og rettsliv, Festskrift til Carsten Smith, 2002 s. 576-579 har jeg gitt flere eksempler på tilsvarende endringer i straffenivået.

3 I Engstrøm (red.): Vegtrafikkloven og trafikkreglene med kommentarer, fjerde utgave, 2004 har jeg behandlet straffutmålingen på s. 440-471. I Lov og Rett 1991 s. 385-386 gir Andenæs uttrykk for skepsis overfor denne praksis.

4 Dette spørsmålet er nærmere behandlet av Matningsdal: Norsk spesiell strafferett, Oslo $2010 \mathrm{~s}$. 221-225.

5 Jf. Innst. S. nr. 192 (1991-92) s. 44 andre spalte.

6 Jf. Forhandlinger i Stortinget (1998-99) s. 3472-3478.

$7 \quad$ Se også Rt. 2002 s. 709, 2002 s. 1139 og 2002 s. 1556.

8 Se også de danske undersøkelsene som omtales av Melchior i Juristen 2009 s. 3-6.

9 Fram til 1. august 1995 ble straffesaker hvor den øvre strafferammen overskred fengsel i seks år, med noen unntak som jeg ikke går inn på, behandlet av lagmannsrettene som førsteinstans. De øvrige sakene, som ble behandlet av herreds- og byrettene som førsteinstans, ble anket direkte 
til Høyesterett bortsett fra at det i visse tilfeller ble gitt samtykke til fornyet behandling i lagmannsretten av bevisbedømmelsen under skyldspørsmålet. Etter to-instansreformen behandles alle straffesaker av tingretten som første instans, og lagmannsrettene er nå gjort til ankedomstol også ved anke over lovanvendelsen, straffutmålingen og saksbehandlingen. Dette har ført til at antallet straffesaker i Høyesterett har blitt betydelig redusert. Se Matningsdal i Lov og Rett 2006 s. 429-458.

10 Dette er Rt. 1995 s. 275,1995 s. 519,1995 s. 672,1995 s. 1007,1995 s. 1180,1995 s. 1216 og 1995 s. 1528.

11 Dette er Rt. 1995 s. 31, 1995 s. 637 (Inr. 36), 1995 s. 637 (lnr. 39), 1995 s. 954 (to domfelte) og 1995 s. 1175.

12 Dette er Rt. 1995 s. 701.

13 Dette er Rt. 1995 s. 718.

\section{Mailadresse:}

magnus.matningsdal\&hoyesterett.no 